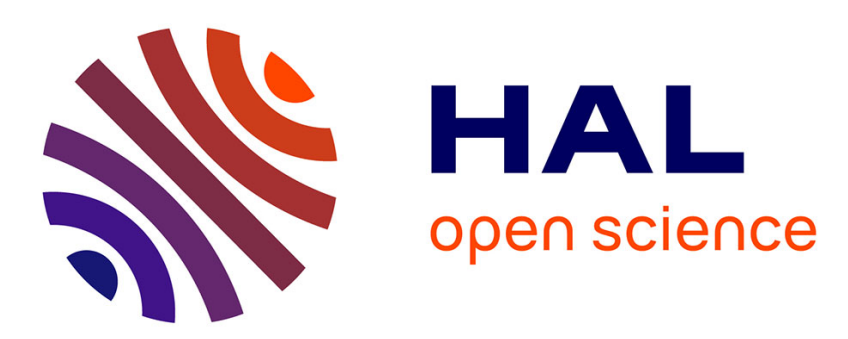

\title{
The Welfare Conventions Approach: A Comparative Perspective on Social Impact Bonds
}

Eve Chiapello, Lisa Knoll

\section{To cite this version:}

Eve Chiapello, Lisa Knoll. The Welfare Conventions Approach: A Comparative Perspective on Social Impact Bonds. Journal of Comparative Policy Analysis, In press, pp.1-16. 10.1080/13876988.2019.1695965 . hal-02538395

\section{HAL Id: hal-02538395 \\ https://hal.science/hal-02538395}

Submitted on 9 Apr 2020

HAL is a multi-disciplinary open access archive for the deposit and dissemination of scientific research documents, whether they are published or not. The documents may come from teaching and research institutions in France or abroad, or from public or private research centers.
L'archive ouverte pluridisciplinaire HAL, est destinée au dépôt et à la diffusion de documents scientifiques de niveau recherche, publiés ou non, émanant des établissements d'enseignement et de recherche français ou étrangers, des laboratoires publics ou privés. 


\title{
The Welfare Conventions Approach: A Comparative Perspective on Social Impact Bonds
}

\author{
Eve Chiapello \\ EHESS, CEMS \\ 54 Boulevard Raspail \\ 75006 Paris \\ France \\ E-Mail: eve.chiapello@ehess.fr
}

\author{
Lisa Knoll \\ Universität Hamburg \\ Fakultät für Wirtschafts- und Sozialwissenschaften \\ Welckerstr. 8 \\ 20354 Hamburg \\ Germany
}

\section{E-Mail: lisa.knoll@uni-hamburg.de}

Eve Chiapello is Professor at EHESS (School for Advanced Studies in Social Sciences), Paris, France, where she holds a chair about the "sociology of the transformations of capitalism". Her present work is about the financialization of public policies.

Lisa Knoll works at University of Hamburg and Martin-Luther-University Halle-Wittenberg in a research project funded by the German Research Council on risk practices in the financial sector and in politics.

This paper is part of the special issue "Comparing the Development of Social Impact Bonds across Different Countries and Policy Sectors" with guest editors Alec Fraser, Clare FitzGerald and Jonathan Kimmitt.

\begin{abstract}
The Social Impact Bond (SIB) is a new funding mechanism for welfare programs. It is supposed to create savings for the public sector from which private returns can be deduced. Presented as a purely technical solution, SIBs discard their political morality. The Welfare Convention Approach (WCA) is designed for studying SIBs as disputed and versatile welfare apparatuses. We claim that elements from diverse historical welfare conventions (the philanthropic, communitarian, civic, market, full employment, entrepreneurial, financial, and behavioral) reveal the diverse institutional conflicts and compromises of SIBs at the time they are implemented. In so doing, the WCA informs comparative research on SIBs.
\end{abstract}


Keywords: Social Finance, Neoliberalism, Government Instruments, Welfare State, Social Policy, Political Economy, Comparative Research

\section{Introduction}

At the World Economic Forum in Davos in 2013, Social Impact Bonds (SIBs) were introduced as an important financial innovation for solving the challenges of the $21^{\text {st }}$ century (SIITF 2014): a win-win-win option that fuels the underfinanced social sector with capital needed, provides new profitable investment opportunities for the financial sector, and helps the state to meet its fiscal requirements. In the standard description, the SIB is understood as a contractual relationship between the government, a social service provider, and investors, in which investors assume the risk of a failed social intervention based on rigorous outcome evaluation. If the intervention produces savings for the state, they are shared with the investors, constituting their return on investment. The SIB has "burst into the public financing scene with astonishing rapidity" (Cooper et al. 2016, 63). To the present day, 132 impact bonds with $\$ 431$ million dollar "capital raised" and 1,064,030 "lives touched" have been launched in 25 countries. $^{1}$

Real SIB set-ups display a high level of heterogeneity, and may depart in important ways from the standard description. They are complex in design and involve multiple actors: At the core is mainly an intermediary organization which raises capital, structures deals, establishes legal vehicles (e.g. a Special Purpose Vehicle), and monitors the performance of service provision and evaluation. An external evaluator, either a university entity or an international accounting organization, needs to determine, with the help of a team of lawyers, if and when a SIB triggers a return on investment on the basis of outcome assessments. The investors can range from highnet worth individuals, foundations, guarantors or grant-makers, social venture capital firms,

\footnotetext{
${ }^{1}$ See https://sibdatabase.socialfinance.org.uk, accessed 2019-07-07.
} 
banks, community development financial institutions, and even government agencies or dedicated public investment funds, such as Big Society Capital in the UK. The service providers are usually non-profit non-governmental organizations, but they can also be cooperatives or for-profit companies. The outcome funders, those reimbursing the investors, are usually local or central governments, but they can also be foundations, or international donor agencies, as in the case of Development Impact Bonds (Alenda-Demoutiez 2019). SIBs bring together a wide variety of actors from different backgrounds, such as social workers, psychologists, volunteers, bankers and venture capitalists, consulting and auditing firms, central and local government officials, and philanthropists, in the hope of providing new social services for single moms, lonely elderly, drug addicts, homeless people, ex-prisoners, residential care receivers, and other welfare state target groups. As a flexible and negotiated mechanism - a "multi-stakeholder partnership" - they are a hotspot of compromise and institutional heterogeneity.

In this article, we propose the Welfare Conventions Approach (WCA) as an analytical lens through which to study this complexity in comparative research designs. The WCA is designed for understanding the disputed and fragmented changes in the "governmentality" of welfare (Rose and Miller 1992). It makes it possible to study the turbulent and dynamic processes of creating new "welfare apparatuses" (ibid., 193) such as SIBs. It helps clarify their dynamics by linking together the various voices and actors, methods, tools and financial relations interwoven within the SIBs, which relate to century-old disputes over the question of welfare. These disputes can be traced to welfare conventions, which offer specific ways of "framing" (Snow and Benford 1988) social problems, thereby identifying dedicated causes and solutions (Gusfield 1989). Each framing of social problems empowers certain actors and entails particular governmental technologies, which can be defined as "the complex mundane programs, calculations, techniques, apparatuses, documents and procedures through which authorities seek to embody and give effect to governmental ambitions" (Rose and Miller 1992, 175). Those technologies include the design of financial circuits that can take on various guises. 
SIBs are promoted as a 'financial innovation'. We claim that the way money and financials are handled and distributed cannot be detached from the political rationalities of welfare. For example, a donation reflects a certain definition of a solution to a social problem via moral obligation, differing fundamentally from tax-financed redistribution based on entitled rights, which again differs from framing welfare as a problem of private underinvestment, suggesting that the solution lies in the design of investor relations. Such linkages between finance and welfare have been highlighted by the comparative literature on welfare regimes (EspingAndersen 1990), which, for example, draws a distinction between the Beveridge welfare model financed through taxes and redistribution and the Bismarck welfare model that relies on social insurance and wages.

In order to introduce the WCA as an analytical lens for understanding SIBs, we first (1.) present the versatile character of the SIB along four dimensions. Second (2.), we outline eight welfare conventions, which prove the intertwined nature of the moral-political and technical-financial dimensions in diverse attempts in the governmentality of welfare. Third (3.), we show how the WCA provides an analytical lens through which to study SIBs in comparative research designs. The WCA helps to unravel the conflicted and compromised welfare conventions that are woven together and rejected in SIBs.

\section{The shapeshifting character of SIBs}

After a decade of implementation, the "shapeshifting' nature" of SIBs has been highlighted (Fraser et al. 2018a, 19). As a voluntarist multi-party funding mechanism, a SIB requires intense work and complex negotiations on the part of the involved parties (Gustafsson-Wright et al. 2015, 30; Neyland 2017, 6) a process in which some projects may turn into alternative funding arrangements such as block contracting, spot purchasing or grants (Fraser et al. 2018a) or may not even be implemented at all. Furthermore, it is quite common to renegotiate the conditions 
of a SIB during its run-time or to end it earlier (as was the case with the first two recidivism SIBs in the UK and the US). On the one hand, the SIB narrative provides a highly adaptable catch-all concept that enables fast diffusion, on the other hand, "the practice and thus the concept of a SIB, and what it should be, continues to evolve with different voices" (Fraser et al. 2018a, 19). To demonstrate the shapeshifting character of SIBs, we have built on publications from the social sciences (such as Cooper et al. 2016; Neyland 2017; Tse and Warner 2018; Warner and Tse 2019; Wirth forthcoming), and evaluation reports (such as Disley et al. 2015; Fraser et al. 2018a). We present the versatile character of SIBs along four dimensions, which have come to be important analytical aspects of the WCA presented later: Social intervention $(1.1)$ - the solution to a particular defined social problem - , the actors involved (1.2), the financial circuits (1.3), and the knowledge, data and metrics (1.4), which all appear to be designed in distinct and multiple ways.

\subsection{Social interventions}

SIBs claim to provide innovative and preventive solutions to social problems such as unemployment, homelessness, children-at-risk or recidivism. The literature displays an interesting diversity, but also limits concerning the possible framings of social problems. Some SIBs tend to articulate social problems as individual deficits located in the psychological, behavioral or motivational characters of persons. Others tend to focus on the closer environment of targeted individuals and address their communities or families. The causes of social ills such as socio-economic inequalities or economic recessions are typically not addressed.

For example, in the UK, the Essex County Council Children-at-Risk SIB aims at preventing out-of-home care or custody through multi-systemic therapy, a trademarked form of family therapy (Neyland 2017). Another example is the special cognitive behavioral therapy advocated in the Rikers Island reoffending SIB. This seeks to improve the moral reasoning of the participants following a step-by-step pattern. The participants progress from one moral stage to 
the next by delivering "testimonies", which aim at the internalization of 12 defined moral stages, beginning with "honesty" and culminating in "choosing moral goals" (Rudd et al. 2013). Here, the causes of the addressed social problem are identified as being within the cognition and psychology of the individual.

In other cases, the intervention, while still focusing on individuals, relies on a different set of assumptions. The London Homelessness SIB or Fair Chance SIBs apply entrepreneurial style casework: social workers "navigate" clients on the basis of specific targets with a small budget to incentivize their participation. Caseworkers and clients are turned into "individual entrepreneurial units" (Cooper et al. 2018, 70) and develop a kind of tit-for-tat relationship around the incentivized targets (Wirth forthcoming). Both clients and caseworkers seem to understand their relationship as a form of commercial arrangement, knowing that targets have value in financial terms. The entrepreneurialization of the target groups is a classic objective of multiple SIBs that address the issue of "workforce development". ${ }^{2}$ These tend to frame this social problem alongside classic politics of activation (Pascual and Magnusson 2007). For example, the French Microcredit SIB and the Buzinezz Club Utrecht SIB support young people in setting up their own business.

Other SIBs frame the social problem they address as a lack of community connections. The UK Worcestershire Reconnections SIB, for example, organizes befriending services with volunteers or self-help groups in order to reduce loneliness and social isolation among people over the age of 50 (Fraser et al. 2018a).

Finally, some SIBs design a form of intervention that improves citizens' entitlements or develops their capacity to exercise their rights. Through the Peterborough Prison SIB, cohorts of prisoners were helped to access services such as housing, jobcentre benefits, healthcare and drug treatment, as necessary (Disley et al. 2015, 36).

\footnotetext{
${ }^{2}$ See https://sibdatabase.socialfinance.org.uk, accessed 2019-05-10.
} 
Note that every framing of social problems excludes alternative ways of problematizing them. Cooper et al. $(2016,66)$, for example, show how the Homelessness SIB discards decades of social research on the multiple factors shaping homelessness. In a similar manner, Warner and Tse (2019) show how the 13 early care and education SIBs studied concentrate intervention on the child/parent microsystem, while leaving the mesosystem (service provider/employer) and macrosystem (state policy/market) untouched.

These few examples show that SIBs may incorporate very specific and distinct definitions and interpretations of the social ills associated with a particular solution (social intervention). The diverse actors collaborating in a SIB do not spontaneously agree on one particular interpretation. Rather, what is ultimately implemented needs to be considered as the result of struggles between actors stemming from different backgrounds, each bringing their resources, techniques, and a certain mindset.

\subsection{Actors}

The construction of a SIB requires the alignment of diverse groups of actors from different professional and moral backgrounds. Thus, the establishment of a SIB involves finding compromises between different approaches to welfare. Furthermore, the roles (investors, service providers, intermediary organisations, etc.) can be played out by diverse actors with different identity and background.

The investors of the first SIB in Peterborough were charitable foundations, as well as social venture funds that can be classified as "mission-related" (Höchstädter and Scheck 2015). Other SIBs involve for-profit investors such as Goldman Sachs, which tend to show substantially less tolerance towards losing money. To de-risk investors such as Goldman, some foundations provide guarantees or subsidies (Warner 2013, 310). Philanthropically financed SIBs tend to differ from those with commercial investors. For example, the philanthropic underpinnings of 
the South Carolina SIB supported an arrangement with no private returns and the transition of philanthropic funds into more permanent welfare state resources (Tse and Warner 2018). Furthermore, the investor can also be the service provider, as was the case with the Homelessness SIBs studied by Cooper et al. (2016). Here, the service providing charity chose to be the main financier, co-investing along with other charities in order to keep profit-driven investors out of the deal.

Social service providers can also be quite distinct. It makes a difference whether a service provider is a large corporation or a small community-based social enterprise. Carter (2019) shows that small, motivated social enterprises are far less attuned to "cherry-picking" easy cases for better results than large for-profit firms working under classic pay-by-results schemes.

Fraser et al. (2018a, 114-115), in their evaluation of the trailblazers in health and social care highlight the importance of the intermediary organization, which can apply different styles of management: some more collaborative and trust-based, others more formal and much less tolerant towards missed key performance indictors (KPIs).

At the same time, SIBs tend to silence other groups such as front-line workers. The Essex County Council SIB chose multi-systemic therapy, without considering the expertise of the social workers. This choice was based on the strength of its evidence-based method, entrepreneurial status, and social workers had to work with it even though they did not consider it useful (Neyland 2017). There is also a tendency for target groups to not be able to express any preference. Warner (2013) notes how SIBs differ in this respect to classic private-public partnerships, where users pay fees or receive vouchers for a service of their choice.

\subsection{Financial circuits}

The question of financial circuits addresses the differences between donations, return on investment, universal tax financed provision, and tax reductions, as well as the various loan structures. SIBs display broad diversity in the rules governing their monetary flows. They built 
on the financial promise of turning public savings into private returns. The identification of these savings lies at the heart of any SIB project, and may be constructed with a focus on the long-term perspective of the welfare state, or with a focus on the short-term interests of the investors. SIBs deal with these conflicts of interest through various, often complex financial structuring.

SIBs can create or draw upon diverse public-private financial arrangements. The government is not only involved via the role of commissioner who pays back the investment in the case of success. It can provide tax relief (e.g. social investment tax relief in the UK), act as co-investor through a public-private fund structure (e.g. Big Society Capital, a social investment bank funded by dormant bank accounts in the UK), or as the "purchaser of social outcomes" (SIITF $2014,2)$. Neyland $(2017,13)$ reports "calculative asymmetries" in contract negotiation between investors and the local authority, which have led to an arrangement whereby financial returns were "frontloaded" as soon as children embarked on therapy. Rate card schemes, such as the Fair Chance Fund, are structured in a similar way to allow payments during the project runtime (Wirth forthcoming). Rate card schemes are used in the UK by funds dedicated to specific social problems, such as the Innovation Fund, the Fair Chance Fund, and the Youth Engagement Fund. These funds act as purchasers of outcomes by defining price tags, such as "Improved behavior at school (Measured by a letter from a teacher) £800”, "Stop persistent truancy (absent for over $10 \%$ of school days per year) $£ 1,300$ ”, “Achievement of First National Qualifications Framework (NQF) Level 2 qualification £2,200” (Gustafsson-Wright et al. 2015, 18).

The literature provides many examples of a conflicted financial distribution among SIB stakeholders. In the Chicago Child-Parent Center SIB, Goldman Sachs managed to receive success payments for 15 years after the intervention, at a high public costs and without any plans for sustained preschool provision, whereas the South Carolina SIB has been re-using their financial return for future service provision, resulting in a transformation of philanthropic funding into stable state-orchestrated funding streams (Tse and Warner 2018). In the Osnabrück 
SIB in Germany, in the case of a successful intervention the local savings bank donates its financial reimbursements "to a social institution or to an educational institution", so that the financial resources remain in the district of Osnabrück and in the "not-for-profit cycle" (Hornung 2017, 2, own translation).

\subsection{Knowledge, data and metrics}

SIBs, like any welfare governing apparatus (Rose and Miller 1992), rely on professional techniques and (statistical) knowledge documenting the social problems. And as pay-forperformance vehicles, SIBs are supposed to be based on a careful evaluation of the actual "impact" in order to be able to identify returns. Data is thus instrumental for the design of the intervention and its evaluation, as exemplified by the Peabody Picture Vocabulary Test used in the Utah SIB to select the children that participate and to draw a comparison later (Tse and Warner 2018).

The choice of a comparator is decisive. This is why the control group trial is considered the gold standard for SIBs (NAO 2015). However, this is the most rarely used method in SIB setups (Gustafsson-Wright et al. 2015). Reasons for this absence might be "the cost of undertaking outcome measurement", the lack of "research expertise" or the "small size of some of the client groups which precluded meaningful quantitative analysis" (Fraser et al. 2018a, 14). Furthermore, commissioners found that the "use of an RCT [randomized control trial] as a counterfactual would be unethical (...) to those who were randomly selected not to receive the interventions" (ibid., 101). This reasoning reveals a conflict with a perception of justice that values non-discriminatory equal access to welfare services. Quite often, there is no impact evaluation in the actual sense of causal determination. SIBs may rely on proxies that measure subjective changes to trigger outcome payments, such as is the case with the self-administered R-UCLA loneliness scale in the Worcestershire Loneliness SIB. Evaluation is based on beforeand-after comparisons, drawing on administrative data such as the number of users of special 
education, placement in out-of-home care, employment status, or incarceration (GustafssonWright et al. 2015, 20).

Evidence of public savings are another important legitimatory feature of SIBs. However, evaluation reports document difficulties in meeting this demand (Gustafsson-Wright et al. 2015). In four out of five healthcare trailblazers, "neither cashable nor hypothetical savings were expected" (Fraser et al. 2018a, 104). Determining public sector savings is a negotiable, versatile and sometimes arbitrary feature of SIB constructions. The cost of welfare state services, an important baseline for comparison, can be put together from quite diverse statistical sources. For example, in the London Homelessness SIB, savings were determined from a baseline of societal costs that included police time, hospital and psychiatric use, jobseeker's allowance, and tenancy breakdowns, but excluded costs from housing benefit uptake, long-term imprisonment, and specific alcohol and drug treatment (Cooper et al. 2016, 72). Furthermore, the historical baseline can alter over time and create a situation in which the "business as usual counter factual" is “no longer 'usual'”, as Neyland $(2017,7)$ puts it. For instance, Essex County Council improved its welfare provision for children-at-risk, while the SIB was still determining its success based on an earlier, and substantially worse, situation.

This shows that data production is not neutral (Desrosières 1998). Data sets and methods cannot be considered in isolation of the framing of social problems and the associated welfare governmentality. Standardized access to public services based on the rule of law produces different data sets from a managerial target-based model of welfare provision. SIBs amalgamize already existing data produced for quite diverse purposes. The composite character of data systems also reveals the diverse and conflicted character of SIBs.

The welfare conventions approach (WCA) provides an analytical hold on this diversity. It is designed to show that the four dimensions of SIBs are not independent of each other. The way the social problem is defined and addressed is linked to the roles played by the actors and their respective statuses, and also to the ways in which financial circuits are built, which in turn are 
dependent on the kind of data and knowledge designed to create and stabilize the particular arrangement. However, at the same time, the study of SIBs reveals that the alignment between the four dimensions is never perfect. The actors involved are too diverse, and they struggle in their attempts to enforce their own rationality. They have to engage in compromises and the resulting actual SIBs are quite heterogeneous.

\section{The Welfare Conventions Approach (WCA)}

The French Conventions School offers a promising approach for studying the heterogeneity of SIBs. The theoretical approach commenced in France in the 1980s as an attempt to investigate economic processes as morally disputed (Thévenot 2006). As such, it does not differentiate between social and political questions and technical and economic ones. Rather, economic mechanisms and instruments are analyzed as embodiments of specific - and historically diverse - forms of justice and fairness (Boltanski and Thévenot 2006) and historical transformation emanates from disputes and compromises between these "orders of worth" (Boltanski and Chiapello 2005, Chiapello 2013). According to this approach, welfare apparatuses such as SIBs can be studied as conflicted arrangements, where diverse polities have to be aligned and compromised. A similar analytical program arguing for the concomitance of contradictory values in contemporary institutional set-ups is the institutional logics perspective (Thornton et al. 2012).

The WCA recalibrates existing analytical repertoires in order to define a list of "welfare conventions" dedicated to the question of welfare organization. Rose and Miller's work has been helpful in our endeavor to include public and private forms of welfare governance. In their Foucaultian analysis of the historical changes in the British National Health Service, they claim the importance of analyzing diverse "attempts to know and govern the wealth, health and happiness of populations" (Rose and Miller 1992, 175). To them government is not restricted 
to official state organizations, but to the whole (public and private) network of institutions, knowledge forms and devises with which the government of welfare comes into play. Welfare is not limited to the classic welfare state, but consist of the whole range of techniques, "from double entry book-keeping to compulsory medical inspection of schoolchildren" (ibid., 177178). In their view, the government of welfare aligns "political rationalities" with "governmental technologies" of diverse kinds.

The welfare conventions developed in this article reveal the four dimensions outlined in the previous section: They embody a definition of the social problem, which comes with particular causes and solutions. They determine an important and responsible actor to solve the problem, and design financial circuits accordingly (such as rich people giving money to charities caring for the poor - the philanthropic convention, or a state taxing its citizens to provide equal public services - the civic convention). Finally, the functioning of this special organization produces and requires specific data and knowledge forms. SIBs, like any welfare apparatus, reveal these four dimensions of welfare provision.

The following section describes eight welfare conventions in a stylized way. Each of them provides its own political rationality supported by specific governmental technologies. They never exist in a pure form, but they are present in contemporary welfare discourses and elements of them appear to be institutionalized in actual welfare regimes. Because they are incorporated into existing welfare state structures, they shape SIBs when applied in the real world. Actors rely on them when they construct, justify, negotiate, and criticize SIBs.

The proposed set of welfare conventions results from a close examination of the SIB phenomenon and its disputes with established forms of welfare governance. The purpose is to disentangle the diverse rationalities that give SIBs their particular shape, such as the fact that they appear to be restricted to an entrepreneurial project and designed for the purpose of generating financial profits. SIBs are ususally planned as projects (entrepreneurial convention), they tend to adress the behavioral/psychologcial patterns of individuals (behavioural 
convention), they are designed to attract investors (financial conventions), and they often require philanthropists to back-up the private investments (philantropic convention). However, we also aim to provide more classic conceptualizations of welfare that SIBs seem to be at odds with. Indeed, SIBs do not develop in a tabula rasa, but in a world full of institutions rooted in pre-existing welfare state arrangements. The communitarian, civic and full employment conventions were at the center of the development of the welfare state after World War II, and the market convention was at the heart of the neoliberal turn in the post-Fordist era (Jessop 1991). This spectrum of welfare conventions provides an analytical heuristic to study current conflicts and compromises surrounding SIBs in diverse institutional settings. The eight welfare conventions sharpen the understanding of different ways of addressing social problems that interact, conflict, and find compromise in SIBs. 


\begin{tabular}{|c|c|c|c|c|c|c|c|c|}
\hline Welfare conventions & Philanthropy & Communitarian & Civic & Full employment & Market & Entrepreneurial & Financial & Behavioral \\
\hline \multicolumn{9}{|c|}{ Political rationalities } \\
\hline $\begin{array}{l}\text { Social problem } \\
\text { Reason to be in need }\end{array}$ & Destiny, immorality & Isolation, egoism & $\begin{array}{l}\text { Lawlessness, socio- } \\
\text { economic inequalities }\end{array}$ & $\begin{array}{l}\text { Lack of good quality } \\
\text { jobs, economic } \\
\text { recession }\end{array}$ & $\begin{array}{l}\text { Inertia, nepotism, } \\
\text { inefficiency }\end{array}$ & $\begin{array}{l}\text { Passive, shy, and } \\
\text { risk-adverse behavior }\end{array}$ & $\begin{array}{l}\text { Below market return } \\
\text { on investment }\end{array}$ & $\begin{array}{l}\text { Irrational behavior, } \\
\text { habits, and emotions }\end{array}$ \\
\hline Solution & $\begin{array}{l}\text { Compassion, mercy, } \\
\text { giving }\end{array}$ & $\begin{array}{l}\text { Self-organization, } \\
\text { mutualism, } \\
\text { membership, } \\
\text { corporatism }\end{array}$ & $\begin{array}{l}\text { Entitlements, rights, } \\
\text { law-based social } \\
\text { service provision }\end{array}$ & $\begin{array}{l}\text { Contracyclical } \\
\text { interventions, } \\
\text { industrial policy, } \\
\text { protective labor law }\end{array}$ & $\begin{array}{l}\text { Efficacy of } \\
\text { competition and the } \\
\text { market-place }\end{array}$ & $\begin{array}{l}\text { Empowerment, } \\
\text { capacity building, } \\
\text { activation, network, } \\
\text { innovation }\end{array}$ & $\begin{array}{l}\text { Impact investing, } \\
\text { micro-credit, } \\
\text { investment readiness } \\
\text { policies }\end{array}$ & $\begin{array}{l}\text { Behavioral therapy, } \\
\text { nudging }\end{array}$ \\
\hline $\begin{array}{l}\text { Responsible actors } \\
\text { Who should care? }\end{array}$ & $\begin{array}{l}\text { Chivalry of wealth, } \\
\text { aristocracy, } \\
\text { foundations, } \\
\text { volunteers }\end{array}$ & $\begin{array}{l}\text { Community, group, } \\
\text { association }\end{array}$ & $\begin{array}{l}\text { Politicians linked to } \\
\text { public } \\
\text { administrations }\end{array}$ & $\begin{array}{l}\text { Keynesian } \\
\text { macroeconomists, } \\
\text { economy planners }\end{array}$ & $\begin{array}{l}\text { Rational individuals } \\
\text { for themselves }\end{array}$ & $\begin{array}{l}\text { (Social) } \\
\text { Entrepreneurs }\end{array}$ & $\begin{array}{l}\text { Financial investors, } \\
\text { banks }\end{array}$ & $\begin{array}{l}\text { Therapists, } \\
\text { neuroscientists, } \\
\text { behavioral } \\
\text { economists }\end{array}$ \\
\hline \multicolumn{9}{|c|}{ Governmental technologies } \\
\hline $\begin{array}{l}\text { Financial circuits } \\
\text { Flows in money and } \\
\text { in kind }\end{array}$ & Charity, donation & $\begin{array}{l}\text { Reciprocity, } \\
\text { solidarity, sharing, } \\
\text { mutual insurance }\end{array}$ & $\begin{array}{l}\text { Taxation, } \\
\text { redistribution, public } \\
\text { service provision, } \\
\text { budget plan }\end{array}$ & $\begin{array}{l}\text { Wages, salaries, } \\
\text { industry subsidies }\end{array}$ & $\begin{array}{l}\text { Market exchange, } \\
\text { vouchers, consumer } \\
\text { subsidies }\end{array}$ & $\begin{array}{l}\text { Contracts, deals, } \\
\text { pay-for-performance }\end{array}$ & $\begin{array}{l}\text { Investments, return } \\
\text { on investment }\end{array}$ & $\begin{array}{l}\text { Stimulus and answers } \\
\text { (non-monetary) }\end{array}$ \\
\hline $\begin{array}{l}\text { Knowledge } \\
\text { Statistics, accounting, } \\
\text { quantification }\end{array}$ & $\begin{array}{l}\text { Living conditions of } \\
\text { those in misery }\end{array}$ & $\begin{array}{l}\text { Membership } \\
\text { statistics, collective } \\
\text { group interests }\end{array}$ & $\begin{array}{l}\text { Inequality, income } \\
\text { and wealth } \\
\text { distribution, social } \\
\text { policies }\end{array}$ & $\begin{array}{l}\text { National accounts, } \\
\text { economic growth }\end{array}$ & $\begin{array}{l}\text { Market indicators } \\
\text { (e.g. volume, price, } \\
\text { market shares, } \\
\text { liquidity) }\end{array}$ & $\begin{array}{l}\text { Business plans, } \\
\text { performance, } \\
\text { marketing }\end{array}$ & $\begin{array}{l}\text { Risks and returns, } \\
\text { (social) ratings }\end{array}$ & $\begin{array}{l}\text { Psychological } \\
\text { individual traits, } \\
\text { behavioral patterns }\end{array}$ \\
\hline
\end{tabular}

Table 1) Conventions of welfare, own composition 
The philanthropic convention is grounded in the moral duty of the wealthy to help those in need. Differences (such as inequalities) belong to an eternal order that should not be challenged (Chiapello 2013). Power and wealth are concentrated into the hands of the few, who must in return care for the poor and the weak, and the aging and the ailing. The elites act as moral role models, living a decent life. They form, in the words of Marshall (1907) the "chivalry of wealth" that should be honored "as men honored the mediaeval chivalry of war". The poor need to show their respect towards these elites by showing decent moral habits and thankfulness. Even without giving money, people can contribute by volunteering and devoting their time to those in need. The knowledge collected focuses on those living in misery, and not gathered about the wealthy.

The communitarian convention of welfare seeks for solutions in a community-based form of self-organization (based neither on individuals nor on the state). The corporatist state of EspingAndersen (1990) fits here, as well as the reciprocity pattern of economic circulation identified by Polanyi (1944). The communitarian model is based on membership and group organization. Social security is provided on a mutual basis as in the first social insurances. It is important to know to which group one belongs and to show solidarity within it. These groups could be employer or employee associations, such as the German co-determination system or communities based on origin, religion, or place of residence, as in the US polity.

The civic welfare convention is based on universal civil and human rights and is grounded in the republican ideas of equality and liberty. Here, the quest for the formal equality of citizens is important. Welfare is defined by means of democratic processes and guaranteed by the rule of law. States impose taxes on their citizens in order to provide universal public services. The Beveridge welfare model, based on taxation and redistributive transfers, represents the civic welfare convention best. The civic statistical endeavors concern all social classes for the purpose of establishing a fair system of taxation and redistribution. Citizens are served by a 
professional public administration that guarantees impartial standards in public service provision in dedicated fields (education, health, employment, research, or culture).

The full employment (Fordist) welfare convention bases welfare on salaries and wages. The central political aim is full employment, to make sure no one is left behind. States intervene by means of macro-economic oversight and anti-cyclical investment programs to prevent economic crises. Social security can be organized through protectionism, subsidizing industries, and strengthening workers' rights. Infrastructure investments, purchasing programs and protective labor law are the main instruments. Like the civic welfare model, the full employment model requires taxation to finance public expenses. However, contrary to the civic convention, this model favors expenditure to create good quality jobs rather than welfare services for those excluded. In the Bismarckian welfare state, the full employment welfare model is associated with the communitarian convention. Here, solidarity is generated between workers who finance social security systems, and far less between the citizens of a nation state. The market model of welfare requires a market society that has turned even work, money, and nature into (fictitious) commodities (Polanyi 1944). It demands that all income stems from selling and buying activities. In a perfect market society, poverty is an individual choice and as such deserved. It is therefore not necessary to care for the poor; this is considered to be paternalistic (Hayek 1944). The market welfare model ensures that everyone can act as a market agent. A market solution to a social question can thus have multiple guises: one is a fair tendering process for competing social service providers. Another market-based welfare policy shifts producer-side subsidies to consumer-side subsidies (Salamon 2012). This means building financial circuits that create constellations of demand and supply, which often requires guaranteeing liquidity and a critical mass of competitors.

The entrepreneurial model of welfare seeks to solve the social problem through the initiative of flexible and innovative entrepreneurs and project developers. Social entrepreneurship (Cameron 2012) is rooted in this convention, as well as initiatives that aim at transforming 
anyone into an entrepreneur, in particular the unemployed, who should be 'activated' (Pascual and Magnusson 2007). Moreover, social venture capitalism requires entrepreneurial attitudes from investors who should not be investing from a distant, neutral position, but rather be involved in the invested projects. Performance and impact measurement schemes help to objectify and to communicate 'success'. Philanthrocapitalism (McGoey 2014) can be seen as a compromise between the entrepreneurial and the philanthropic convention.

The financial welfare convention seeks to solve the social problem by converting it into a problem of investment (Chiapello 2015). In “a world awash with capital - some \$200 trillion in financial assets" (Cohen and Sahlman 2013) private profit-driven capital becomes the solution (and not the problem) of welfare. Social projects and people need to become investible, which requires e.g. the establishment of social impact ranking systems (Barman 2015). The financial welfare convention shifts the focus of the policy to the private financers and the investment-seeking capital, which involves raising the rates of return and de-risking riskadverse investors in order to attract their capital (Chiapello 2019, Keohane et al. 2013). All the others (the entrepreneurs, the service providers, the beneficiaries, the welfare state) are redefined as potential investees (Feher 2018).

The behavioral welfare convention is informed by psychological insights (Pykett 2017) on emotions, habits and routines and the inadequacies of individual choice due to the countless cognitive biases of individuals. Causes and effects of behavioral patterns are identified on the basis of rigorous testing, using scientifically validated scales and experimental designs from the field of medicine. Experimental testing requires making differences between recipients and control groups, creating an inequality that would not be acceptable under other conventions (e.g. civic). It has been neuro-scientifically proven that people cannot be held responsible for their actions. The outcome of individual choices are governed or "nudged" (Thaler and Sunstein 2008) via changes in their environment. They need to be placed within an ecosystem where they are happy and healthy and the outcomes can be measured (Davies 2016). Incentives are 
not necessarily monetary, but could include peer-to-peer influence, spatial design, social marketing, the nudging of unconscious behavioral patterns, and behavioral or cognitive therapy (Whitehead et al. 2014).

The WCA offers an analytical framework through which to unravel the diverse institutional strands that are woven together or rejected in SIBs. On the one hand, the language of SIBs is relatively flexible, allowing alliances to be drawn with the entirety of the welfare conventions presented above, at least in discursive terms. On the other hand, the WCA emphasizes that welfare conventions are not merely discursive, but materialize very specific socio-technical setups with specific framings of the social problem, financial circuits, management tools and data production in place. This materiality makes it difficult to move from one convention to another and create compromises between them. In order to build a SIB, the contradictions between welfare conventions have to be resolved in one way or another. Thus, SIBs may differ in response to particular institutional constellations. The following section explains how the WCA can inform comparative research designs on SIBs.

\section{Comparative research designs on SIBs}

Comparative research has proven to be a valuable strategy for studying SIBs. Comparative studies conducted include a study on the first recidivism SIBs in the US and the UK (Ogman 2019), one on three childcare SIBs in the US (Tse and Warner 2018), research that was later extended to 13 early education SIBs (Warner and Tse 2019), the comparative evaluation report on the trailblazer SIBs in health and social care, which compares SIBs and non-SIBs, and identifies three models of SIB from five SIB case studies (Fraser et al. 2018a), a study comparing three UK and one Canadian health care SIB (Caré and de Lisa 2019), and a study by Carter (2019), who compares a SIB with a non-SIB approach, a valuable research strategy, as it places SIBs within their wider welfare state context. 
The WCA is designed to provide an analytical lens through which to strengthen such comparative research strategies. It highlights the efforts of the SIB protagonists to construct a stable arrangement in a heterogeneous and contradictory world of welfare institutions. Even though a SIB is a very specific socio-technical apparatus, it has to build on diverse welfare rationalities, professional expertise, instruments and institutions. Developing comparative research designs with the WCA requires unravelling the elements stemming from different welfare conventions that are interwoven and confronted by SIBs, and showing how the conflicts and contradictions shapeshift the established welfare governing arrangement.

SIBs typically adhere to the behavioral, financial, and entrepreneurial welfare conventions. In their standard description, SIBs oppose pure philanthropy (although many SIBs rely on mission-driven investors), civic 'scattergun funding' (although their business model is based on tax-financed welfare), and they tend to oppose the market convention, even though they are presented as a market mechanism by its protagonists. The Essex County Council SIB studied by Neyland (2017) paradigmatically combines the behavioral framing of the social question, applying multi-systemic therapy (MST) with a contractual set-up that is organized to secure financial return for the investors. The return is "front loaded" each time a child embarks on MST, an amount related to future "days of care averted". As such, it is a financialized SIB but not necessarily a marketized one. Indeed, Neyland argues that it became an "anti-market device", preventing competition while allowing large financial returns. Interestingly, even though the SIB was set up as an entrepreneurial contract, it became inflexible. A "change from MST would require a whole new contract which also "would never happen"” due to a yearslong negotiation process of the targets associated with the social intervention (ibid., 9).

The WCA highlights such contradictions inherent in SIB constructions. It stresses the demanding institutional requirements that come with a particular claim (such as stable financial returns) and it steers the attention to the incompatibility of interests and objectives and the struggles to build common institutional ground. This is a demanding process requiring the 
replacement or reshuffling of welfare conventions. For example, Fraser et al. (2018a, 49) identify that local commissioners were at first unwilling to support the service provider. Their "underlying commissioning principle was one of "open competition"” and "competitive tendering by multiple providers" (market convention). The commissioner had to develop a much less distant attitude and become part of the project and its success (entrepreneurial convention).

This kind of contention between welfare conventions leads to institutional change and may even turn projects planned as SIBs into alternative funding models. The Peterborough SIB, for example, was terminated earlier than planned due to the implementation of a statutory provision of universal probation services (civic convention) that rendered the SIB superfluous (Disley et al. 2015). The comparative study by Tse and Warner (2018) reveals how welfare conflicts in SIBs can be resolved differently and infuse the wider welfare state debate: In the Utah SIB, the conflict between the civic and the financial convention led to a new legal compromise. The negative press over high private returns resulted in preschool legislation, broadening public funding that "caps the interest rate at 5\% above the municipal market general obligation data bond rate" (Tse and Warner 2018, 9). The above-mentioned South Carolina SIB rejected the concept of private profit entirely and established state orchestrated preschool funding from philanthropic resources, resulting in a civic-philanthropic compromise.

The WCA encourages scholars to study not only successfully implemented SIBs, but also those that encounter problems in being aligned with their institutional environment. SIBs are not isolated projects but belong to a state-guaranteed financial, technical, cultural and legal infrastructure. Just as market solutions for public goods are unevenly distributed (Warner and Hefetz 2002), SIBs do not turn up everywhere. In Germany, for example, one SIB was implemented in 2013, with a second and third much later on in 2017. The "institutional barriers" to SIBs are notably higher in Germany than in the US and the UK. Some protagonists blame the reluctant and inflexible German welfare associations (Benford and Birnbaum 2016) - a 
civic-communitarian compromise -, others the German Budget Law, which requires a SIB to prove ex-ante that it is more efficient than an alternative funding model (Fliegauf et al. 2015). This law more or less establishes what Fraser et al. demand for the UK, namely "that policymakers considering a SIB contract make a realistic ex ante assessment (...) rather than assuming that any SIB will deliver a 'win-win' solution" (Fraser et al. 2018b, 16). In this respect, the German budget law seems to be less flexible and/or entrepreneurial.

Currently, SIBs are under development in at least 34 countries $^{3}$ and we do not know what the outcome of these efforts will be. The WCA is designed to inform comparative research designs on SIBs by providing an analytical hold on their conflicts in diverse welfare institutional environments. As such, it can inform comparative research designs between SIBs and other welfare apparatuses (Carter 2019), between SIBs in similar contexts (Tse and Warner 2018), and between SIBs in diverse institutional contexts (such as the UK and Germany).

\section{Conclusion}

SIBs have been analyzed as a signpost of broader trends, such as marketization (Joy and Shields 2013), financialization (Dowling 2017) or neoliberalism (Cooper et al. 2016). The WCA enables a finer-grained understanding of these broader analytical categories in showing how diverse welfare conventions are combined and opposed in concrete SIB arrangements. In doing so, it combines two research perspectives: On the one hand, it emphasizes the importance of determining the broader politico-economic trends represented by the SIBs, while on the other also adhering to the importance of studying the complexity and heterogeneity of their appearance. We agree with Davies, who states: “the economic 'imperialism' of neoliberalism comes to appear far less homogenous and all-consuming than its critiques might fear. Different

\footnotetext{
${ }^{3}$ See https://sibdatabase.socialfinance.org.uk, accessed 2019-07-29.
} 
political and sovereign objects require different conventions of evaluation in order to be rendered measurable and economically calculable" (Davies 2014, 27).

The WCA offers an analytical repertoire to investigate SIBs (and the welfare disputes they evoke) taking into account not only the conventions obviously involved (such as financial or entrepreneurial), but also those that tend to be silenced (such as civic or full employment) and often accused to be 'critical' or 'moral' and less 'evidence-based'. It emphasizes that moral and rational dimensions cannot be separated in analytical terms, and one cannot escape morality by the promises of evidence-based policies. Rather, the definition of a social problem is linked to particular financial arrangements and social interventions, defining who is in charge, who gains and pays financially, and who has a voice. Thus, everybody engaged in the establishment of a SIB (those who have a voice) assumes critical and defensive roles. The SIB protagonists tend to criticize the inefficiency of established forms of welfare provision, their lack of evidence, or missing innovativeness. However, they also attract criticism from other perspectives, on issues such as privatization, unequal treatment, or their lack of understanding of economic booms and recessions. Seen through the lens of the WCA, failed SIBs do not necessarily represent failure, but a success in the light of alternative welfare conventions.

Any welfare apparatus embodies and enacts a combination of welfare conventions. The WCA captures welfare apparatuses such as SIBs not as monolithic tools, but as institutional configurations constantly on the move, driven by the forces and dynamics of welfare disputes. This versatility and heterogeneity makes SIBs interesting subjects for comparative research designs. The conflicts encountered within SIBs reveal differences concerning the wider institutional contexts into which they are placed with greater or lesser success. SIBs can be seen as a wonderful opportunity through which to investigate broader historical transformations in the welfare state that have been acted upon and brought about within the process of a constant search for compromise. 


\section{References}

Alenda-Demoutiez, J., 2019. A fictitious commodification of local development through development impact bonds? Journal of Urban Affairs

Barman, E., 2015. Of Principle and Principal: Value Plurality in the Market of Impact Investing. Valuation Studies, 3 (1), 9-44.

Benford, J. and Birnbaum, J., 2016. Social Impact Investment in Deutschland. Marktbericht 2016: Kann das Momentum genutzt werden? Gütersloh: Bertelsmann Foundation.

Boltanski, L. and Thévenot, L., 2006. On justification: Economies of worth. Princeton: Princeton University Press.

Boltanski, L. and Chiapello, E. (2005). The New Spirit of Capitalism. London, New York: Verso.

Cameron, H., 2012. Social Entrepreneurs in the Social Innovation Ecosystem. In: A. Nicholls and A. Murdock, eds. Social Innovation: Blurring Boundaries to Reconfigure Markets. London: Palgrave Macmillan, 199-220.

Carè, Rosella and De Lisa, Riccardo (2019): Social Impact Bonds for a Sustainable Welfare State: The Role of Enabling Factors. Sustainability.

Carter, E. 2019. More than marketised? Exploring the governance and accountability mechanisms at play in Social Impact Bonds. Journal of Economic Policy Reform.

Chiapello, E., 2013. Capitalism and Its Criticism. In: P. Du Gay and G. Morgan, eds. New spirits of capitalism? Crisis, justifications, and dynamics. Oxford: Oxford University Press, 60-81.

Chiapello, E., 2015. Financialisation of valuation. Human Studies, 38, 13-35.

Chiapello, E., 2019. The work of financialisation. In: M. Lenglet, I. Chambost, Y. Tadjeddine, eds.The making of Finance, London: Routledge, 192-200.

Cohen, R. and Sahlman, W.A., 2013. Social Impact Investing Will Be the New Venture Capital. Harvard Business Review, 17.

Cooper, C., Graham, C., Himick, D., 2016. Social Impact Bonds: The Securitization of the Homeless. Accounting, Organizations and Society, 55, 63-82.

Davies, W., 2014. The Limits of Neo-Liberalism: Authority, Sovereignty and the Logic of Competition. London: Sage.

Davies, W., 2016. The Politics of Silent Citizenship: Psychological government and the 'facts' of happiness. In: J. Pykett, R. Jones, and M. Whitehead, eds. Psychological Governance and Public Policy. Governing the mind, brain and behaviour. London: Routledge.

Desrosières, A. 1998. The Politics of Large Numbers - A History of Statistical Reasoning. Cambridge: Harvard University Press. 
Disley, E., et al., 2015. The payment by results Social Impact Bond pilot at HMP Peterborough: final process evaluation report. Ministry of Justice Analytical Series: RAND Europe.

Dowling, E., 2017. In the wake of austerity: social impact bonds and the financialisation of the welfare state in Britain. New Political Economy, 22 (3), 294-310.

Esping-Andersen, G., 1990. The Three Worlds of Welfare Capitalism. Cambridge: Princeton University Press.

Feher, M., 2018. Rated Agency. Investee Politics in a Speculative Age. Cambridge: Zone Books.

Fliegauf, M.T., et al. 2015. Policy Brief. Investition, Intervention, Impact. Der Soziale Wirkungskredit in Deutschland. Berlin: stiftung neue verantwortung.

Fraser, A., Tan, S., Lagarde, M., Mays, N., 2018a. Evaluation of the Social Impact Bond Trailblazers in Health and Social Care. Final report. PIRU Publication 2018-23: PIRU Policy Innovation Research Unit.

Fraser, A., Tan, S., Kruithof, K., Sim, M., Disley, E., Giacomontonio, C., 2018b. Narratives of promise, narratives of caution: A review of the literature on Social Impact Bonds. Social Policy \& Administration, 52 (1), 4-28.

Gusfield, J.R., 1989. Constructing the Ownership of Social Problems: Fun and Profit in the Welfare State. Social Problems, 36 (5), 431-441.

Gustafsson-Wright, E., Gardiner, S., and Putcha, V., 2015. The Potential and Limitations of Impact Bonds. Lessons from the first five years of experience worldwide. Washington D.C.: Brookings. Global Economy and Development Program.

Hayek, F.A., 1944. The Road to Serfdom. Chicago: University of Chicago Press.

Höchstädter, A. K., and Scheck, B., 2015. What's in a Name: An Analysis of Impact Investing Understandings by Academics and Practitioners. Journal of Business Ethics 132, 449-475.

Jessop, B., 1991. The Welfare State in the Transition from Fordism to Post-Fordism. In: B. Jessop, H. Kastendiek, K. Nielsen, O. K. Pedersen, eds. The Politics of Flexibility: Restructuring State and Industry in Britain, Germany and Scandinavia, Edward Elgar, 82104.

Joy, M. and Shields, J., 2013. Social Impact Bonds: The Next Phase of Third Sector marketization? Canadian Journal of Nonprofit and Social Economy Research, 4 (2), 39 55.

Keohane, N., Mulheirn, I., and Shorthouse, R., 2013. Risky Business. Social Impact Bonds and Public Services: The Social Market Foundation.

Marshall, A., 1907. The Social Possibilities of Economic Chivalry. The Economic Journal, 17 (65), 7-29. 
McGoey, L., 2014. The Philanthropic State: Market-state Hybrids in the Philanthrocapitalist Turn. Third World Quarterly, 35 (1), 109-125.

Neyland, D., 2017. On the transformation of children at-risk into an investment proposition: A study of Social Impact Bonds as an anti-market device. The Sociological Review, 66 (3), 492-510.

NAO, 2015. Outcome-based payment schemes: government's use of payment by results. London: National Audit Office.

Ogman, R., 2019. 'Ethical capitalism' in the city. Embedded economy or marketization? The case of social impact bonds. Journal of Urban Affairs.

Pascual, A.S. and Magnusson, L., 2007. Reshaping Welfare States and Activation Regimes in Europe. Bruxelles: Peter Lang.

Polanyi, K., 1944. The Great Transformation. The political and economic origins of our time. Boston: Beacon.

Pykett, J., 2017. Brain Culture. Shaping Policy through Neuroscience. Bristol: Policy Press at the University of Bristol.

Rose, N. and Miller, P., 1992. Political power beyond the state: Problematics of government. British Journal of Sociology, 43 (2), 173-205.

Rudd, T., et al., 2013. Financing Promising Evidence-Based Programs. Early Lessons from the New York City Social Impact Bond. New York: MDRC.

Snow, D.A. and Benford, R.D., 1988. Ideology, frame resonance, and participant mobilization. International Social Movement Research, 1, 197-217.

Thaler, R. and Sunstein, C., 2008. Nudge: Improving Decisions About Health, Wealth, and Happiness. New York: Penguin Books.

Thévenot, L., 2006. Convention School. In: J. Beckert and M. Zafirovski, eds. International encyclopedia of economic sociology. London: Routledge, 111-115.

Thornton, P.H., Ocasio, W., and Lounsbury, M., 2012. The Institutional Logics Perspective. Oxford: Oxford University Press.

Tse, A. and Warner, M., 2018. The razor's edge: Social impact bonds and the financialization of early childhood services. Journal of Urban Affairs

Warner M. and Tse A., 2019. A Policy Outcomes Comparison: Does SIB Market Discipline Narrow Social Rights? Journal of Comparative Policy Analysis

Warner, M. and Hefetz, A., 2002. The Uneven Distribution of Market Solutions for Public Goods. Journal of Urban Affairs, 24 (4), 445-459.

Whitehead M., Jones, R., Howell, R., Lilley, R., and Pykett, J., 2014. Assessing the global impact of the behavioural sciences on public policy. Nudging all over the world.

Aberystwyth: Economic and Social Research Council. 
Wirth, M., forthcoming. Nudging subjects at risk: Social Impact Bonds between financialization and compassion. Historical Social Research 